\title{
Long-term Variations of Chemical Properties in Controlled Horticultural Soils of Gyeongnam Province
}

\author{
Young-Han Lee, Seong-Tae Lee, Kang-Pyo Hong, Sang-Dae Lee, Je-Hong Kim, \\ Yong-Sik Ok ${ }^{1}$, Min-Keun Kim**, and HyeRan $\mathrm{Kim}^{2} *$ \\ Gyeongsangnam-do Agricultural Research and Extension Services, Jinju 660-370, Republic of Korea. \\ ${ }^{1}$ Biochar Research Center, Department of Biological Environment, Kangwon National University, \\ Chuncheon 200-701, Republic of Korea. \\ ${ }^{2}$ Korea Research Institute of Bioscience and Biotechnology, Daejeon 305-806, Republic of Korea
}

(Received: August 12 2013, Accepted: September 3 2013)

\begin{abstract}
The monitoring of chemical dynamic changes in controlled horticultural lands is very important for agricultural sustainability. Field monitoring was performed to evaluate the soil chemical properties of 200 controlled horticultural soil samples in Gyeongnam province every 4 years from 2000 to 2012 . Soil chemical properties such as $\mathrm{pH}$, amount of organic matter, available phosphate, nitrate nitrogen, and exchangeable potassium, calcium, magnesium, and sodium were analyzed. The amount of exchangeable calcium and soil pH were significantly higher in 2012 than in 2000. In 2012, the frequency distribution for values of $\mathrm{pH}$, organic matter, available phosphate, and exchangeable potassium, calcium, and magnesium that were within the optimum range was $16.0 \%, 22.5 \%, 11.5 \%, 3.5 \%, 2.5 \%$ and $5.0 \%$ respectively. Especially, available phosphate and exchangeable calcium were excess level with portions of $76.0 \%$ and $96.5 \%$, respectively. These results indicated that a balanced management of soil chemical properties can reduce the amount of fertilizer applied for sustainable agriculture in controlled horticultural lands.
\end{abstract}

Key words: Chemical property, Controlled horticulture, Available phosphate, Exchangeable calcium

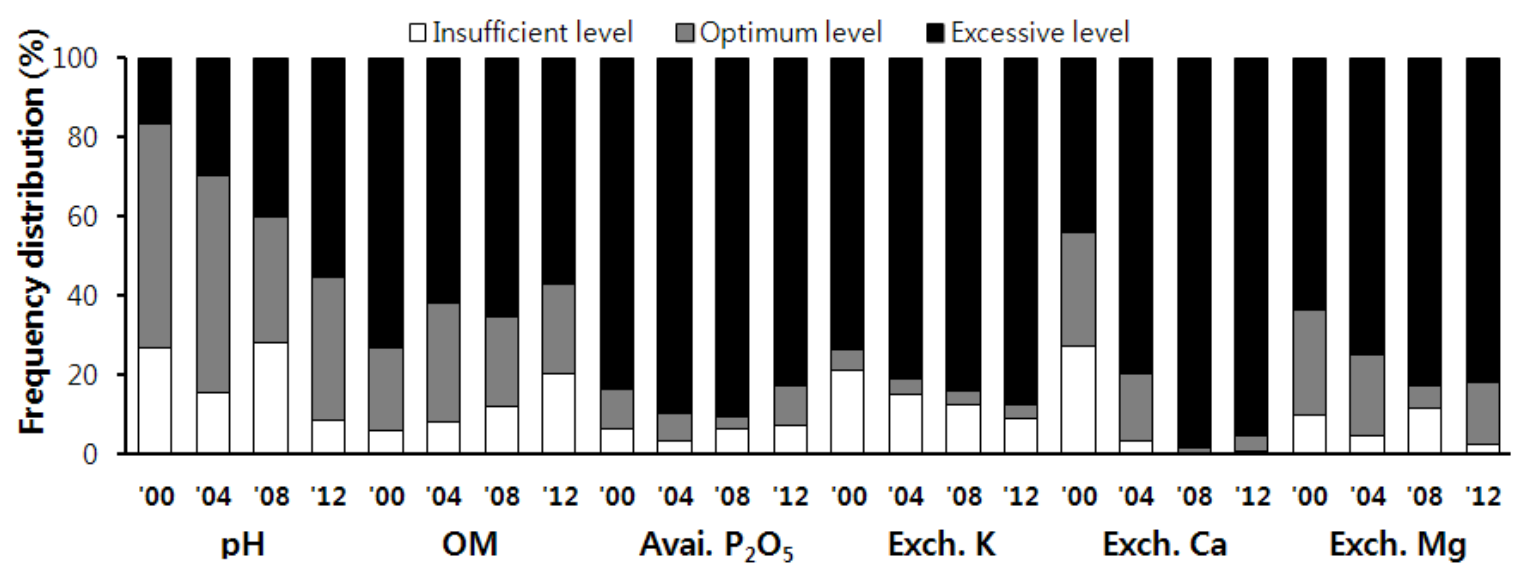

Frequency distribution of chemical properties in controlled horticultural soils of Gyeongnam Province

\footnotetext{
*Corresponding author : Phone: +821020777133, E-mail: kimhr@kribb.re.kr

**Corresponding author : Phone: +82175520854, E-mail: goguma99@korea.kr

${ }^{\S}$ Acknowledgement: This study was conducted with the support of the Research Cooperating Program for Agricultural Science \& Technology Development (Project No. PJ009198242013), RDA, Republic of Korea.
} 


\section{Introduction}

시설 작물의 안정적인 생산을 위해서는 토양의 양분을 진단하여 효율적인 시비관리가 필요하며 이러한 정보를 주 기적으로 제공할 수 있도록 농업환경 변동 모니터링 사업의 확대가 요구 된다 (Kang et al., 2012). 시설재배지 양분의 변동을 조사함으로써 비료 및 토양개량제 공급 등의 정책을 추진할 수 있으며 농가에서는 비료사용량을 절감할 수 있는 정보를 제공할 수 있다. 예전에는 토양 양분을 조사하여 작 물 생산성을 증대시키는 것을 중요하게 생각하였으나 (Hur et al., 1997) 현재는 토양의 양분불균형을 해소하고 용탈 등에 의한 2차 오염을 예방하는 것이 중요하게 되었다 (Cho et al., 2002; Tang et al., 2008). 시설 재배지에서 가축분 퇴비 등 부산물 비료의 과다시용은 적정수준 보다 토양 유 기물은 $54.8 \%$, 유효인산은 $79.9 \%$, 교환성 칼륨은 $70.6 \%$, 교환성 칼슘은 $52.4 \%$, 교환성 마그네슘은 $53.2 \%$ 가 초과하 였다 (Jo and Koh, 2004). 충남지역 딸기 시설재배지에서 가축분 퇴비 시용량이 $30 \mathrm{Mg} \mathrm{ha}^{-1}$ 를 초과하는 경우 적정수 준에 비해 토양 $\mathrm{EC}$ 값은 1.8 배, 유효인산 함량은 3.0 배, 교 환성 칼륨 함량은 2.6 배, 교환성 칼슘 함량은 1.7 배, 교환성 마그네슘 함량은 1.6배 높았으며 (Choi et al., 2010b) 적정 수준 보다 유효인산 함량은 $86.9 \%$, 교환성 칼슘 함량은 $86.0 \%$ 가 초과되어 양분 불균형이 심각한 것으로 나타났다 (Choi et al., 2010a). 시설재배지는 비닐하우스로 강우에 차단되어 토양의 염류가 표토로 이동하여 축적되기 쉬운 조 건이다. 토양에 축적된 염류가 과다될 경우 작물의 생육을 저해할 수 있으므로 염류를 경감하기 위해서는 유기물을 시 용하거나 (Cho et al., 2006), 관개방법을 개선하고 (Cho et al., 2006; Chung et al., 2008), 미생물을 활용하는 (Lee et al., 1996; Lee et al., 1997) 방법 등이 있지만 토양검정에 의한 비료 사용 추천량을 준수하는 것이 근본적인 해결방안 이다. 이러한 관점에서 시설재배지 화학성분의 변동을 주기 적으로 평가함으로 농업 생산성을 향상시킬 수 있을 것으로 판단된다.

따라서 본 연구는 경남지역 시설재배지 200개소를 대상 으로 2000년부터 2012년까지 4년 주기로 토양 화학성분의 변동을 조사하여 주성분분석 등을 통한 주요 변동요인을 평 가하여 토양의 양분관리를 위한 기초자료를 얻기 위하여 수 행하였다.

\section{Materials and Methods}

토양 시료채취 및 분석 경남지역 시설재배지의 화학 성분 변동을 주기적으로 파악하기 위하여 2000년에 지역별 로 토양환경과 주요작물 재배면적 비율을 기준으로 200개 지점을 선정하였고 2012년까지 4년 주기로 동일한 지점을 조사하였다 (RDA, 1983). 토양은 수확기인 4월부터 5월 사 이에 표토를 0-15 cm 깊이에서 $800 \mathrm{~g}$ 정도를 토양시료채취 기를 이용하여 3 반복으로 채취하였다.

토양 분석방법 채취한 토양은 실험실에서 7일간 풍건 하여 $2 \mathrm{~mm}$ 체를 통과된 것을 화학성 분석에 사용하였다. 화학성 분석은 농촌진흥청 농업과학기술원 토양 및 식물체 분석법 (NIAST, 2000)을 적용하여 $\mathrm{pH}$ 와 $\mathrm{EC}$ 는 토양과 증류 수의 비율을 1:5로 하여 $\mathrm{pH}$ meter (Orion $520 \mathrm{~A} \mathrm{pH}$ meter, Orion Research Inc., Boston, USA)와, EC meter (Orion 3STAR EC meter, Orion Research Inc., Boston, USA)로 측정하였고, 유기물은 Tyurin법으로 정량하였으며, 유효인 산은 Lancaster 법으로 비색계 (Shimadzu Co., Kyoto, Japan) 를 사용하여 분석하였다. 교환성 양이온으로 칼륨, 칼슘, 마 그네슘, 나트륨 등은 $1 \mathrm{M} \mathrm{NH} \mathrm{NA}_{4} \mathrm{Oc}$ 로 추출하여 ICP (Optima 5300 DV, PerkinElmer Co., Shelton, USA)로 분석하였고 질산태 질소는 킬달증류법으로 분석하였다.

다변량 주성분 분석 및 통계분석 통계분석은 SAS 프로그램 9.1.3 버젼 (2006)을 사용하였다. 연도별 토양 화 학성분은 5\% 수준에서 Fisher's least significant difference (LSD) 검정을 하였고 토양 화학성분의 주성분 분석을 통하 여 연도별 차이를 비교 검토하였다.

\section{Results and Discussion}

연도별 시설재배지 토양 화학성분 경남지역 시설재 배지 토양 화학성의 2012년도 전체 평균은 적정 수준보다 EC 1.4배, 유기물 1.1배, 유효인산 1.8배, 교환성 칼륨 2.7 배, 교환성 칼슘 2.1 배, 교환성 마그네슘 1.9 배 높게 나타났 다 (Table 1). 교환성 칼슘 함량은 2000년에 $6.4 \mathrm{cmol}_{\mathrm{c}} \mathrm{kg}^{-1}$ 이었고 2004년 $10.1 \mathrm{cmol}_{\mathrm{c}} \mathrm{kg}^{-1}$ 으로 증가하였으며 2012년에 다시 $12.5 \mathrm{cmol}_{\mathrm{c} \mathrm{kg}} \mathrm{kg}^{-1}$ 으로 유의적인 증가 상태를 나타냈다.

Table 1. Chemical properties of controlled horticultural field in Gyeongnam Province $(n=200)$.

\begin{tabular}{|c|c|c|c|c|c|c|c|c|c|}
\hline Year & $\mathrm{pH}$ & $\mathrm{EC}$ & $\mathrm{OM}$ & Avail. $\mathrm{P}_{2} \mathrm{O}_{5}$ & K & $\mathrm{Ca}$ & $\mathrm{Mg}$ & $\mathrm{Na}$ & $\mathrm{NO}_{3}-\mathrm{N}$ \\
\hline & $(1: 5)$ & $\mathrm{dS} \mathrm{m}^{-1}$ & $\mathrm{~g} \mathrm{~kg}^{-1}$ & $\mathrm{mg} \mathrm{kg}^{-1}$ & \multicolumn{4}{|c|}{---- Exch. Cation $\left(\mathrm{cmol}_{\mathrm{c}} \mathrm{kg}^{-1}\right)$} & $\mathrm{mg} \mathrm{kg^{-1 }}$ \\
\hline 2000 & $6.3 \mathrm{c}^{\dagger}$ & $3.61 \mathrm{~b}$ & $39 \mathrm{a}$ & $862 \mathrm{c}$ & $1.69 \mathrm{~b}$ & $6.4 \mathrm{c}$ & $3.3 \mathrm{c}$ & $0.86 \mathrm{a}$ & $177 \mathrm{a}$ \\
\hline 2004 & $6.6 \mathrm{~b}$ & $2.62 b$ & $36 \mathrm{~b}$ & $990 \mathrm{~b}$ & $1.56 \mathrm{~b}$ & $10.1 \mathrm{~b}$ & $3.5 \mathrm{bc}$ & $0.66 \mathrm{~b}$ & $136 b$ \\
\hline 2008 & $6.3 \mathrm{c}$ & $2.95 \mathrm{a}$ & $36 b$ & $1,265 \mathrm{a}$ & $1.93 \mathrm{a}$ & $10.5 b$ & $3.9 \mathrm{a}$ & $0.71 \mathrm{ab}$ & $135 b$ \\
\hline 2012 & $7.0 \mathrm{a}$ & $2.88 \mathrm{~b}$ & $39 \mathrm{a}$ & $895 \mathrm{c}$ & $2.13 \mathrm{a}$ & $12.5 \mathrm{a}$ & $3.7 \mathrm{ab}$ & $0.86 \mathrm{a}$ & $107 \mathrm{~b}$ \\
\hline $\begin{array}{c}\text { Optimal } \\
\text { level }^{\ddagger}\end{array}$ & $6.0 \sim 6.5$ & $<2.0$ & $25 \sim 35$ & $350 \sim 500$ & $0.70 \sim 0.80$ & $5.0 \sim 6.0$ & $1.5 \sim 2.0$ & - & - \\
\hline
\end{tabular}

\footnotetext{
${ }^{\dagger}$ Tukey's Studentized Range Test at 5\% level.

\# NIAST (2010): Fertilizer recommendation for crops.
} 
질산태 질소 함량은 2000 년에 $177 \mathrm{mg} \mathrm{kg}^{-1}$ 으로 가장 높았 으며 2004년 이후 유의적인 감소를 보였다. 유효인산 함량 은 2000년에 $862 \mathrm{mg} \mathrm{kg}^{-1}$ 에서 2008년 1,265 mg kg으로 유 의적으로 높았으나 2012 년에 $895 \mathrm{mg} \mathrm{kg}^{-1}$ 으로 낮아지는 추 세였다. 이러한 경향은 Choi et al. (2010b)이 보고한 바와 같이 가축분 퇴비의 과다 시용에 의한 부작용으로 판단되었 다. 교환성 칼륨 및 나트륨 함량은 2004년 이후 지속적으로 유의적인 증가를 나타냈다.

시설재배지 양분 과부족율 경남지역 시설재배에 필 요한 토양 양분의 분포비율은 Fig. 1 과 같다. 토양 $\mathrm{pH}$ 는 적 정수준인 6.0 에서 6.5 의 범위보다 부족한 비율은 2000년 $27.0 \%, 2004$ 년 15.5\%, 2008년 28.0\%, 2012년 8.5\%로 낮아 지는 반면, 과잉비율은 2000년 16.5\%, 2004년 29.5\%, 2008 년 40.0\%, 2012년 75.5\%로 높아지는 경향이었다. 그리고 $\mathrm{pH}$ 와 밀접한 관련이 있는 교환성 칼슘 함량도 과잉비율이 2000년 44.0\%, 2004년 79.5\%, 2008년 98.5\% 및 2012년 $96.5 \%$ 로 2004년 이후 심각한 불균형 현상을 나타냈다. 이 러한 경향은 NIAST (2009)가 전국 시설재배지 1,334 개소의 교환성 칼슘 함량 과잉비율이 2000년 53.4\%, 2004년 62.9\%, 2008년 88.2\%로 지속적인 증가를 보고한 결과와 일치하였 다. 특히, 토양의 칼슘 함량이 많아지고 $\mathrm{pH}$ 가 높아지게 되 면 토양에서 철, 망간, 아연 등 미량성분의 유효도가 크게 낮아져 작물 생육에 결핍현상이 나타날 수 있으므로 적정 $\mathrm{pH}$ 와 석회시용이 시급한 것으로 판단되었다. 따라서 토양 교환성 칼슘 함량을 적정수준으로 유지하기 위해서는 석회 소요량 분석을 통한 토양개량제를 시용토록 농민의식 교육 이 시급한 것으로 생각된다 (Choi et al., 2010b). 토양 유기 물 함량은 적정수준인 25-35 g kg 인 비율이 2000년에 $21.0 \%, 2012$ 년에는 $22.5 \%$ 로 비슷한 수준을 유지하였으나 과잉비율은 2000년 73.0\%, 2004년 62.0\%, 2008년 65.5\% 및 2012년 57.0\%로 높은 비율을 유지하였다. Arancon et al. (2006)은 적정한 유기물 시용은 작물의 생육 및 수량 증 대와 토양 미생물의 유의적인 증가를 기대할 수 있다고 하 였으나 가축분퇴비 등을 과잉시용 하였을때 토양의 인산 축 적 등의 문제를 야기할 수 있으므로 토양 유기물 함량을 적 정수준으로 관리해야 할 것이다. 토양의 유효인산 함량은 적정수준인 $350-500 \mathrm{mg} \mathrm{kg}^{-1}$ (NIAST, 2010) 비율은 2000
년 10.0\%, 2004년 7.0\%, 2008년 3.0\% 및 2012년 11.5\%이었 으며 과잉된 비율은 2000년 83.5\%, 2004년 89.0\%, 2008년 $90.5 \%$ 및 2012년 $76.0 \%$ 로 심각한 양분 불균형 현상을 나타 냈다. 이러한 결과는 Tagliavini et al. (2005)이 보고한 바 와 같이 인산의 시비효율이 낮고, Choi et al. (2010a)이 보 고한 바와 같이 가축분퇴비 등의 과량시비에 기인한 것으로 판단되었다. 그리고 NIAST (2009)가 2008년에 전국 시설재 배지 1,334 개소의 토양 유효인산 함량 초과비율이 $80.8 \%$ 로 매우 높았다고 보고한 결과와 일치하였다. 따라서 시설재배 지의 유효인산 함량을 적정수준으로 유지하기 위해서는 인 산성분이 적은 유기물 시용과 토양 검정에 의한 인산시비가 필요하다 (NIAST, 2010). 교환성 칼륨 함량은 적정수준인 $0.7-0.8 \mathrm{cmol}_{\mathrm{c}} \mathrm{kg}^{-1}$ 보다 과잉된 비율은 2000년 $73.5 \%$, 2004년 81.0\%, 2008년 84.0\% 및 2012년 87.5\%로 매우 높게 나타났다. 이러한 결과는 교환성 칼슘과 마그네슘에서도 비 슷한 경향을 보여 교환성 양이온의 과잉현상이 심각한 것으 로 나타났다.

시설재배지 화학성분 상관관계 토양 화학성분간의 상관관계는 Table 2 와 같다. 토양 $\mathrm{pH}$ 는 교환성 칼륨, 칼슘, 마그네슘, 나트륨과 고도의 유의성 있는 정의 상관을 나타 낸 반면, $\mathrm{EC}$ 와 질산태 질소 함량과는 부의 상관을 나타냈다 $(p<0.001)$. 시설재배지 $\mathrm{pH}$ 와 $\mathrm{EC}$ 값이 부의 상관을 보인 이유는 $\mathrm{Ca}$ 염들의 침전 때문인 것으로 생각되었다 (Choi et al., 2010a). 시설재배지의 $\mathrm{EC}$ 값은 질산태 질소 함량과 고 도의 유의성 있는 정의 상관 $(\mathrm{r}=0.771, p<0.001)$ 을 보였 으며 유기물 함량, 유효인산, 교환성 칼륨, 마그네슘 및 나 트륨 함량과도 정의 상관을 나타냈다. 유기물 함량은 유효 인산, 질산태 질소, 교환성 양이온들 (칼륨, 칼슘, 마그네 슘)과 고도의 정의 상관을 보였다. 이러한 결과는 유기물의 공급원으로 양분을 다량 함유한 가축분퇴비 등을 농가에서 많이 시용한 때문인 것으로 판단되었다 (Choi et al., 2010b). 교환성 칼슘 함량은 교환성 마그네슘 함량과 고도 의 정의 상관을 나타냈다. 시설재배지의 연도별 화학성분 주성분 분석결과는 Fig. 2 와 같다. 화학성분 9 가지의 주성 분 분석으로 $\mathrm{PC} 1$ 은 $37.9 \%, \mathrm{PC} 2$ 는 $19.6 \%$ 를 나타냈으며 전 체 $57.5 \%$ 의 비율을 보였다. 토양 화학성분의 PC 1 주성분은 교환성 칼륨 (1.511), 교환성 마그네슘 (1.488), EC (1.449),

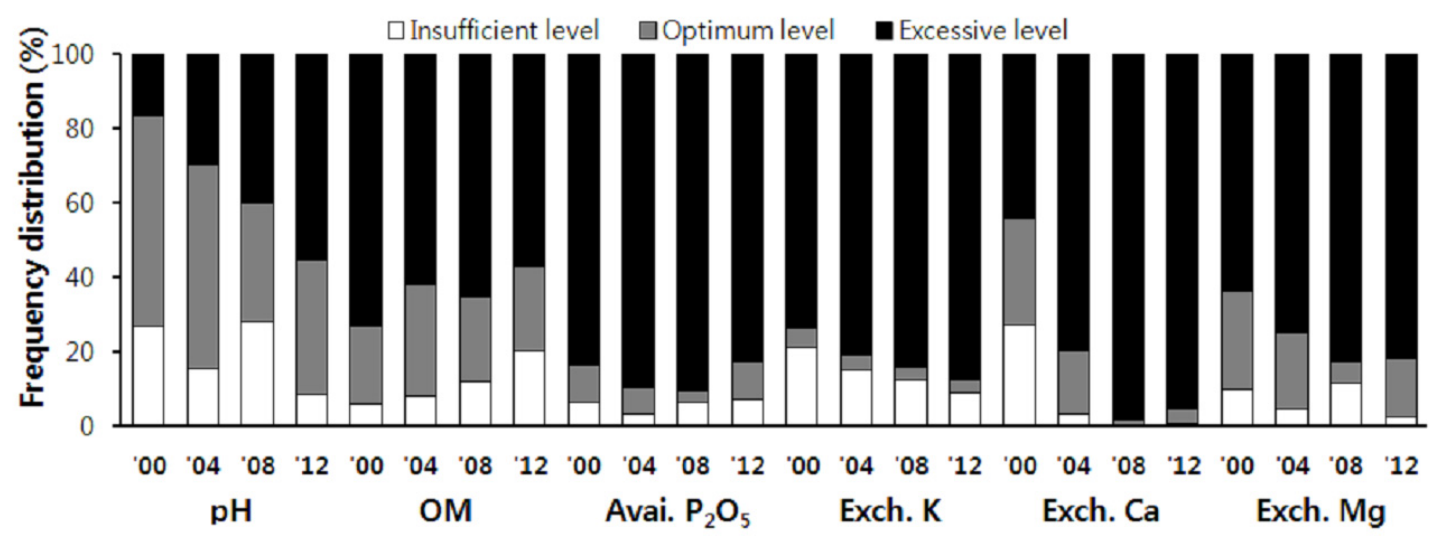

Fig. 1. Frequency distribution of chemical properties of controlled horticultural field in Gyeongnam Province $(n=200)$. 
Table 2. A comelation coefficient between chemical properties of strawbeny cultivated soils $(n=800)$.

\begin{tabular}{|c|c|c|c|c|c|c|c|c|}
\hline & $\mathrm{EC}$ & $\mathrm{OM}$ & Avail. $\mathrm{P}_{2} \mathrm{O}_{5}$ & $\mathrm{NO}_{3}-\mathrm{N}$ & Exch. K & Exch. Ca & Exch. Mg & Exch. $\mathrm{Na}$ \\
\hline $\mathrm{pH}$ & $-0.104^{* * * *}$ & -0.027 & 0.003 & $-0.241^{* * * *}$ & $0.108^{* * * *}$ & $0.507^{* * * *}$ & $0.235^{* * *}$ & $0.147^{* * *}$ \\
\hline $\mathrm{EC}$ & & $0.225^{* * *}$ & $0.219^{* * *}$ & $0.771^{* * *}$ & $0.518^{* * *}$ & 0.013 & $0.555^{* * *}$ & $0.519^{* * *}$ \\
\hline $\mathrm{OM}$ & & & $0.413^{* * *}$ & $0.216^{* * *}$ & $0.545^{* * *}$ & $0.228^{* * * *}$ & $0.415^{* * *}$ & 0.035 \\
\hline Avail. $\mathrm{P}_{2} \mathrm{O}_{5}$ & & & & $0.293^{* * *}$ & $0.454^{* * * *}$ & $0.196^{* * *}$ & $0.302^{* * *}$ & $0.063^{*}$ \\
\hline $\mathrm{NO}_{3}-\mathrm{N}$ & & & & & $0.398^{* * *}$ & $-0.060^{*}$ & $0.377^{* * *}$ & $0.271^{* * *}$ \\
\hline Exch. K & & & & & & $0.279^{* * *}$ & $0.603^{* * *}$ & $0.270^{* * *}$ \\
\hline Exch. Ca & & & & & & & $0.379^{* * *}$ & $0.067^{*}$ \\
\hline Exch. Mg & & & & & & & & $0.388^{* * *}$ \\
\hline
\end{tabular}

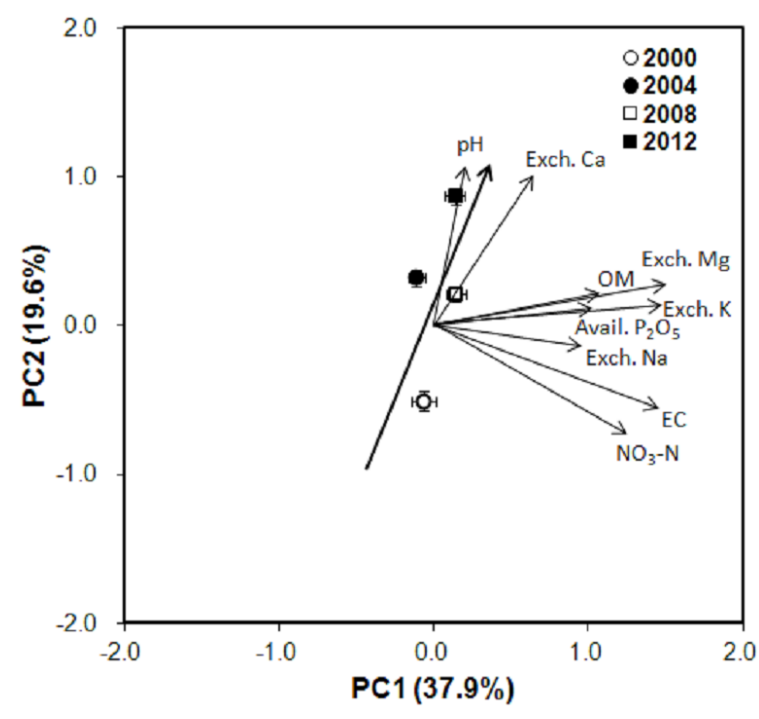

Fig. 2. Principal components analyses of chemical properties of chemical properties of controlled horticultural field in Gyeongnam Province $(n=800)$. The variance explained by the each principal component (PC) axis is shown in parentheses. Bars present standard emor.

및 질산태 질소 (1.234)가 관련되었으며 $\mathrm{PC} 2$ 는 $\mathrm{pH}$ (1.015) 및 교환성 칼슘 (1.009)이 관련되었다. 주성분 분석결과 연 도별 $\mathrm{pH}$ 및 교환성 칼슘 함량의 변화가 뚜렷하게 나타나 토 양검정을 통한 토양개량제의 시용이 매우 중요한 것으로 생 각된다.

\section{References}

Arancon, N.Q., C.A. Edwards, and P. Bierman. 2006. Influences of vermicomposts on field strawberries: Part 2. Effects on soil microbiological and chemical properties. Bioresource Technol. 97:831-840.

Cho, J.Y., K.W. Han, J.K. Choi, Y.J. Kim, and K.S. Yoon. 2002. $\mathrm{N}$ and $\mathrm{P}$ losses from a paddy field plot in central Korea. Soil Sci. Plant Nutr. 48:301-206.

Cho, K.R., C.S. Kang, T.J. Won, and K.Y. Park. 2006. Effects of compressed expansion rice hull application and drip irrigation on the alleviation of salt accumulation in the plastic film house soil. Korean J. Soil Sci. Fert. 39:372-379.

Choi, M.T., J.I. Lee, Y.U. Yun, J.E. Lee, B.C. Lee, E.S. Yang, and Y.H. Lee. 2010a. Characteristics of fertility on strawberry cultivated soil of plastic film house in Chungnam Province in Korea. Korean J. Soil Sci. Fert. 43(2):160-165.

Choi, M.T., J.I. Lee, Y.U. Yun, J.E. Lee, B.C. Lee, E.S. Yang, and Y.H. Lee. 2010b. Relationship between fertilizer application level and soil chemical properties for strawberry cultivation under greenhouse in Chungnam Province. Korean J. Soil Sci. Fert. 43(2):153-159.

Chung, B.Y., K.S. Lee, M.K. Kim, Y.H. Choi, M.K. Kim, J.Y. Cho. 2008. Salt accumulation and desalinization of rainfall interception culture soils of Rubus sp. in gochang-gun, Jeollabuk-do. Korean J. Soil Sci. Fert. 41:310-317.

Hur, B.K., S.K. Rim, Y.H. Kim, and K.Y. Lee. 1997. Physico-chemical properties on the management groups of paddy soils in Korea. Korean J. Soil Sci. Fert. 30(1):62-66.

Jo, I.S., and M.H. Koh. 2004.. Chemical changes in agricultural soils of Korea: data review and suggested countermeasures. Environ. Geochem. Hlth. 26:105-117.

Kang, S.S., A.S. Roh, S.C. Choi, Y.S. Kim, H.J. Kim, M.T. Choi, B.K. Ahn, H.W. Kim, H.K. Kim, J.H. Park, Y.H. Lee, S.H. Yang, J.S. Ryu, Y.S. Jang, M.S. Kim, Y.K. Sonn, C.H. Lee, S.G. Ha, D.B. Lee, and Y.H. Kim. 2012. Status and changes in chemical properties of paddy soil in Korea. Korean J. Soil Sci. Fert. 45(6):968-972.

Lee, Y.H., M.S. Yang, and H.D. Yun. 1996. Effect of plant-growth-promoting-bacteria inoculation on the growth and yield of red pepper (Capsicum annuum L.) with different soil electrical conductivity level. Korean J. Soil Sci. Fert. 29:396-402.

Lee, Y.H.,, W.S. Cho, J.G. Kim, H.S. Lee, S.R.l Park, and H.D. Yun. 1997. Effect of plant-growth-promoting bacteria inoculation on the growth and yield of cucumber (Cucumis sativa L.). Korean J. Soil Sci. Fert. 30:196-199.

NIAST (National Institute of Agricultural Science and Technology). 2000. Analytical methods of soil and plant. NIAST, Suwon, Korea.

NIAST (National Institute of Agricultural Science and Technology). 2010. Fertilizer recommendation for crops. 
RDA, Suwon, Korea.

NIAST (National Institute of Agricultural Science and Technology). 2009. Annual report of the monitoring project on agro-environmental quality in 2008. RDA, Suwon, Korea.

RDA (Rural development administration). 1983. Soil in Korea. RDA, Suwon, Korea.

SAS. 2006. SAS 9.1.3 Version. SAS Inst., Cary, NC.

Tagliavini, M., E. Baldi, P. Lucchi, M. Antonelli, G. Sorrenti, G.
Baruzzi, and W. Faedi. 2005. Dynamics of nutrients uptake by strawberry plants (Fragaria $X$ Ananassa Dutch.) grown in soil and soilless culture. Europ. J. Agronomy 23:15-25.

Tang, J., B. Zhang, C. Gao, and H. Zepp. 2008. Hydrological pathway and source area of nutrient losses identified by a multi-scale monitoring in an agricultural catchment. Catena 72:374-385. 